\title{
Current results of an arachnological survey of some sandstone rock sites in Bohemia (so-called "rock cities")
}

\author{
Vlastimil RUZICKA
}

Abstract. Current results of an arachnologlcal survey of some sandstone rock sites in Bohemia (so called "rock cltles"). The spider fauna of the Adrspach-Teplice rocks was investigated. Some records on spider fauna of other nine sandstone rock areas are included. The phenomenon of 'rock cities' manifests itself in three aspects: (1) In the bottom parts are microclimatically cold spaces, frequently hosting northern or mountain species of invertebrates, which herehave an azonal occurrence. (2) The sun exposed tops of rocks can host thermophllous species. (3) Some species are limited to the surface of rocks and boulders. These are referred to as lithophilous or lithoblont specles.

Key words: Araneae, sandstone, rocks, lithobiont.

\section{INTRODUCTION}

Massive layers of Upper Cretaceous block sandstones jut out at many sites in the northern and northeasternBohemianCretaceous Basin. The presence of fissures, and the different resistance of the individual sandstone layers, induce weathering of the initially compact sandstone plates and thereby the development of diverse shapes. Narrow rocky gorges originated from the destruction of fissure zones, which proceeded particularly by mechanical weathering, mostly by cryogenic erosion, as a result of freezing of water trickling down the fissures. Further shaping of the ground was contributed to by gravitational motions, by the breakdown of rocks, by erosion through water streams, by the effect of snow accumulating in the gorges, etc. Typical macroforms of the relief of sandstone regions are narrow gorges and broad canyons. Additional weathering gives rise to isolated rocks or to rock systems with labyrinths of narrow corridors which, in their perfect form, can constitute the well-known "rock cities". Typical mesoforms of sandstone relief are pseudokarst caves. A great abundance of niches, ledges and honeycombs are found on the surface of rocks and boulders. 
"Rock cities" have their own specific microclimate. The upper parts of rocks and open rock walls oriented to the south are parched, and in sunny days "overheated". Narrow, deep gorges and caves, on the other hand, keep cold air all the year round. Local air currents, water streams and, in particular, slipped-down snow, which can persist in the galleries till summer, also play a role for the microclimate. The extreme cold is the cause of the inversion of vegetation zones in gorges. The degree of inversion may allow the formation of subalpine plant communities.

BALATKA \& SLADEK (1984) gave an overview of the geomorphology of the whole block sandstones area in the Bohemian Cretaceous Basin. They report on twenty-two geomorphological subdistricts, which are characterised by the presence of "rock cities".

\section{STUDY AREA AND METHODS}

The Adrspach-Teplice rocks attain altitudes of 470 to $780 \mathrm{~m}$, they lie in the $\mathrm{CH} 7$ cold climatic region (QUITT 1975), squares of grid-mapping of organisms 5362 and 5462 (BUCHAR 1982). The area of the whole rock complex is about $28 \mathrm{~km}^{2}$.

Fig. 1 Dally course of tem perature in the settlement Adrspach (uppercurve) and in the Karlova Ulicka gorge In the "rock city" (lower curve) (from DOHNAL 1950).

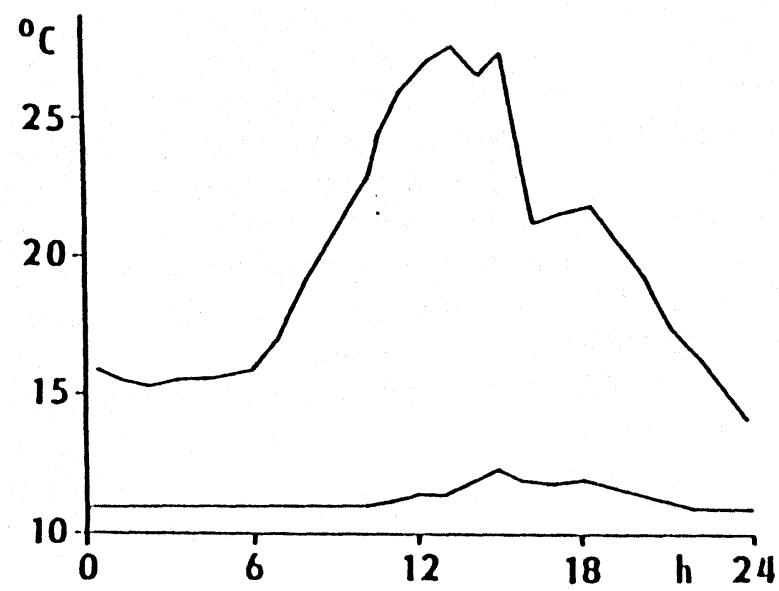


Two typical, well-developed "rock cities" occur in this region. The Adrspach rocks are rich in solitary formations. The height of the rocks reaches $60 \mathrm{~m}$.

The Teplice rocks are bulky and include classical canyon valleys, whereas solitary formations are sparse; the rock height attains $70 \mathrm{~m}$. Between the two compact "rock cities" are extensive areas of gorges and rock labyrinths. Various types of caves have also developed. The entire region is crossed from the west to the east by the VIci Rokle gorge (VITEK 1979). In the coldest spaces of the "rock cities", snow persists to July and the temperature is constantly below $10^{\circ} \mathrm{C}$ (Fig. 1). Alpine and mountain plant species (Viola biflora, Mulgedium alpinum, Homogyne alpina) and arcto-alpine moss species (Andreaea petrophila) occur in the gorges, and the rare high-mountain bryophyte Scapania uliginosa grows in streams (DOHNAL 1950, SYKORA \& HADAC 1984).

The spider fauna of the Adrspach-Teplice rocks was studied intensively in autumn. The first material from the Adrspach-Teplice rocks was collected by $A$. and V. RUZICKA in July 1986. In 1986-1989 J. KOPECKY collected spiders at root stalagmite localities in pseudokarst areas of the Broumovska Vrchovina highland. The results stimulated field trips in October 1987 and in November 1990. Material was collected by sieving, sweeping, beating, and hand-collecting on rocks, under stones, etc., as well as by treating samples of moss and upper soil layers in a Tullgren funnel.

With respect to their position and to the grid-mapping of organisms, the sites visited were divided as follows:

1. The Adrspach "rock city" region (square 5362). Collection was accomplished on rocks of the "rock city" and of the Rerichova Rokle and VIci Rokle gorges, at the peat bog below the Adrspasske Jezirko lakelet, at the peat bog near the upper branch of the blue tourist path, among stones near the brook, on the southwardly exposed slopes of the Vici Rokle gorge covered by heather and by overheating tussocks of dry fern.

2. The Teplice "rock city" region (square 5462). The material was collected at the U Ozveny site, on the top rocks of the Strmen castle, near the mouth and vent-hole of the Teplicka Jeskyne cave, in this debris cave, on rocks near the Korenka cave in the upper section of the rocks, inside the "rock city" and the underground spaces of the Bludiste (Labyrinth) region.

Besides some records of non-systematic spider-collections of nine other rock areas are included. The areas are listed in Tab. 3 , a location map is given in Fig. 2. 
A total of 1'019 spiders, belonging to 82 species, was collected in the Adrspach-Teplice rocks (Tab. 1). The majority was collected in the coldest spaces of the Teplice "rock city" and in leaves and thick moss on block debris near the mouth and vent-hole of the Teplicka Jeskyne cave. Seventeen species $(21 \%)$ were relicts of the 1st rank, i.e., their centre of occurrence is at sites very similar to the original natural conditions (BUCHAR 1983, 1989): Araeoncus crassiceps, Bathyphantes simillimus, Centromerus arcanus, C. pabulator, Dicymbium tibiale, Diplocentria bidentata, Diplocephalus helleri, Drepanotylus uncatus, Hilaira excisa, Lepthyphantes arciger, L. monticola, L. mughi, L. obscurus, L. pallidus alutacius, Poecilonetaglobosa, Porrhomma convexum, and Typhochrestus digitatus. These species constituted as much as $38 \%$ of specimens collected. Abundant occurrence of the Drepanotylus uncatus species was only observed in Sphagnum in the Vici Rokle gorge. The species Centromerus arcanus, Dicymbiumtibiale, Hilaira excisa, and Lepthyphantes monticola were found partly in Sphagnum in the VIci Rokle gorge and partly in the Teplice rocks, whereas the remaining 1st rank relicts occurred only in the Teplice rocks. Fourteen out of the seventeen 1st rank relicts were psychrophilous species (sensu BUCHAR 1975, 1989), occurring mainly in the oreophyticum, in the regions of the mountain flora of Czechoslovakia

Tab. 1 Review of the material from the Adrspach rock city reglon and Teplice rock city reglon. Thermopreference (BUCHAR 1975, 1989) and relict status (BUCHAR 1983, 1989): P . psychrophllous, $N$ - non specific, $M$ - mesotherm, $T$ - thermophll, I - 1st rank rellct, II - and rank rellct, E - expansive specles. o'/ $9 / \mathrm{J}$.

P II Segestria senoculata (L., 1758)

Adrspach Teplice

PE Nesticus cellulanus (CL., 1757) rocks rocks

P II Bathyphantes approximatus (O.P.-CBR., 1871)

$\begin{array}{cc}- & 1 /- \\ -11 & 1 / 1 \\ -/ 1 & - \\ 2 / 3 & 1 / 1 \\ 1 / 2 & -/ 2 \\ - & 1 /- \\ 17 / 21 & 49 / 83 \\ -/ 1 & 1 / 2 \\ 7 / 11 & 11 / 4 \\ - & 1 / 2\end{array}$

NII B. gracills (BL., 1841)

P II B. nigrinus (WESTR., 1851)

NE $\quad$ B. parnulus (WESTR., 1851)

PI B. similimus (L. KOCH, 1879)

P II Bolyphantes alticeps (SUND., 1832)

PI Centromerus arcanus (O.P.-CBR., 1873)

PI C. pabulator (O.P.-CBR., 1875) 
NE C. sylvaticus (BL., 1841)

PE Diplostyla concolor (WIDER, 1837)

P II Drapetisca soclalis (SUND., 1835)

PI Drepanotylus uncatus ((O. P.-CBR., 1873)

$P$ II Helophora inslgnis (BL., 1841)

PI Hilaira excisa (O. P.-CBR., 1871)

P II Labulla thoracica (WID., 1834)

P II Lepthyphantes alacris (BL., 1853)

PI L. arclger (KULCZ., 1881)

P II L. cristatus (MENGE, 1866)

NII L. mansuetus (THOR., 1875)

PI L. monticola (KULCZ., 1881)

PI L. mughl (FICK, 1875)

PI L. obscurus (BL., 1841)

?I L. pallidus alutacius SIM., 1884

P II Lulcher (KULCZ., 1881)

P II L. tenebricola MID., 1834)

P II Unyphia clathrata SUND., 1829

?E L. montana (CL., 1758)

NE L. triangularis (CL., 1758)

NII Macrargus rufus (WID., 1844)

NE Meloneta rurestris (C. L. K., 1836)

NE Microlinyphla pusilla (SUND., 1829)

N II Microneta varla (BL., 1841)

PI Poeclloneta globosa (WID., 1834)

P II Pityohyphantes phrygianus (C. L. K., 1836)

PII Porthomma convexum (WESTR., 1861)

PII P. pallidum JACKS., 1913

P. sp.

PI Araeoncus crassiceps (WESTR., 1861)

NE A. humilis (BL., 1841)

P II Asthenargus helveticus SCHENKEL, 1936

PII Cnephalocotes obscurus (BL., 1834)

NI Dicymbium tiblale (BL., 1836)

PI Diplocentria bidentata (EMERTON, 1882)

PE Diplocephalus cristatus (BL., 1833)

PI D. helleri (L. K, 1869)
Adrspach

rocks

$1 /$ -

$-11$

$2 / 3$

$16 / 28$

$\begin{array}{cc}- & -11 \\ -11 & -11 \\ - & -11 / 5\end{array}$

30/22

$99 / 79$

$-11$

21.

$3 / 5$

$-11$

1/-

$7 / 19$

13/16

$1 /-$

$-12$

$-110$

$2 / 6$

$-12$

.16

2/2/1

$-11$

$1 / 8$

$1 / 4$

$-11$

$2 / 3$

$2 / 3$

$-11 / 1$

1/1

$-11$

$1 /-11$

$1 / 1$

$3 / 7$

$-11 / 1$

$1 / 1$

$16 / 45$

$-11$

$-11$

$1 / 1$

$-/ 1$

1/-

$1 / 1$

$6 / 1$

1/-

17/21

$-11$ 
N II D. lattions (O. P.-CBR., 1863)

$P \| \quad$ Dismodicus blfrons (BL., 1841)

PE Erigone dentipalpls (WID., 1834)

$1 / 2$

PII Erigonella hlemalis (BL., 1841)

$-11$

PII Gonatium rubellum (BL., 1841)

$-7$

P II Gongylidiellum latebricola (O. P.-CBR., 1871)

$1 / 2$

$P E$ Micrargus herbigradus (BL., 1854)

$1 / 1$

$11 / 17$

P II Oedothorax agrestis (BL., 1853)

NE O. apicatus (BL., 1850)

$5 / 10$

P II Pelecopsis elongata (WID., 1834)

$-11$

NE Pocadicnemis pumila (BL., 1841)

$3 / 4$

PE Thyreosthenlus parasiticus (WESTR., 1851)

$-16$

TI Typhochrestus digitatus ((O. P.-CBR., 1872)

$9 / 15$

$-12$

NII Walckenaeria antica (WID., 1834)

-

N II W. mitrata (MENGE, 1868)

PE Meta menardl (LATR., 1804)

$1 /-$

P II

M. mengel (BL., 1869)

PE M. merlanae (SCOP., 1763)

$-/ 1$

$3 / 1$

$-13$

$-12$

N II Tetragnatha pinicola L. K., 1870

$-11$

PE Pardosa amentata (CL., 1758)

$-1 / 13$

NII P. lugubris (WALCK., 1802)

$-1-11$

NII Coelotes terrestris (WID., 1834)

$-/ 1$

$-11$

NII Tegenaria sivlestris (L. K., 1872)

$3 / 2$

$-/ 1$

NE Dlctyna uncinata THOR., 1856

$4 / 4$

$-/ 3 / 4$

$-/ 1$

P II Clublona reclusa (O. P.-CBR., 1863)

$1 / 1$

NII Zora spinimana (SUND., 1833)

$1 / 2 / 1$

$-1 / 11$

NE Xysticus audax (SCHR., 1803)

$\begin{array}{lll}-11 & -11 \\ -13 & -12\end{array}$

NE X. cristatus (CL., 1757)

$-13$

$-12$

NII Neon reticulatus (BL., 1853)

$-12$ 
(SLAVIK 1984; HEJNY \& SLAVIK 1988). Only Typhochrestus digitatus is athermophilous species, Dicymbium tibiale is nonspecific, and the character of the subspecies Lepthyphantes pallidus alutacius is not clear. The species Araeoncus crassiceps, Centromerus arcanus, C. pabulator, Dicymbium tibiale, Diplocephalus helleri, Lepthyphantes arciger, L. mughi, L. obscurus and Porrhomma convexum occur nearly exclusively or predominantly in mountain altitudes.

The material was collected both on rock and on vegetation. As to rock walls, the collecting was performed predominantly in shaded, inverse locations. A part of the material was from more open, exposed locations. Confining ourselves to rocks and to surfaces of boulders, we can pick out a group of species characteristic for this environment. Based on the differences between the sites and abundances of the species, we can set up an approximate sequence of species with respect to their occupation of

Tab. 2 Percentage of specimens of characteristic species in collection from rock surface on various locallites of Adrspach-Teplice rocks and Broumovske Steny walls. Lepthyphantes pulcher, L. alacris, Thyreosthenius parasiticus, Drapetisca socialis, Bathyphantes simillimus, Nesticus cellulanus, Micrargus herbigradus, Diplocephalus hellerl. Total number of specimens.

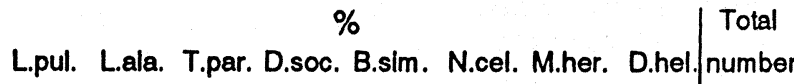

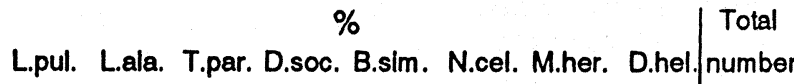

Strmen - wind-swept bare top parts of rocks 60

Korenka -shaded rocks in forest on structural plateau Adrspasske skaly - open parts on the "rock city"

Berichova rokle - shaded rocks in forest gorge

Kovarova rokle - deep rock gorge

Bludiste, Teplicka jeskyne

- underground spaces in debris cave

Teplicke skaly - the coldest narrow parts of the "rock city"

\begin{tabular}{cccccccc|c}
60 & 40 & - & - & - & - & - & - & 5 \\
- & 38 & 25 & 6 & 31 & - & - & - & 16 \\
3 & 3 & 14 & - & 77 & 3 & - & - & 30 \\
- & - & 21 & - & 79 & - & - & - & 19 \\
- & 13 & - & - & 87 & - & - & - & 8 \\
& - & - & - & 86 & 7 & 7 & - & 14 \\
\hline+ & 2 & - & 1 & 90 & 1 & 1 & 6 & 97
\end{tabular}


the rock walls in the height profile, from upper parts exposed to weather down to the bottom shaded cold parts (Tab. 2). Two opposite extremes which overlap slightly are the lithobiont species Lepthyphantes pulcherand Bathyphantes simillimus. The former occupies predominantly exposed parts of rocks, whereas the latter occupies shaded and wet parts of rocks in narrow gorges, fissure-type caves and underground spaces of debris caves. Furthermore, from the top downwards the rock walls are occupied by the species Lepthyphantes alacris, Thyreosthenius parasiticus, Drapetisca socialis, Nesticus cellulanus, Micrargus herbigradus and Diplocephalus helleri.

\section{DISCUSSION}

The abundance of the psychrophilous mountain species in the Teplice "rock city" is a consequence of the exceedingly cold microclimate of their ground and underground parts. The unusual character of this site is also demonstrated by the fact that, although lying in the same climatic region as the Broumovske Steny and the Tiske Steny walls, only the AdrspachTeplice rocks are included in the oreophyticum, the phytogeographic region of the mountain flora of Czechoslovakia (HEJNY \& SLAVIK 1988).

The spider material of nine further rock sites, though not systematically collected, allows a few comments on the occurence of some abundant or exclusive species (Tab. 3).

The most characteristic species of the coldest parts of the AdrspachTeplice rocks, Ostas table mountain and Broumovske Steny walls, is Bathyphantes simillimus. One female of this species was trapped in the coldest part of the Besedicke Skaly rocks, on the ceiling of a rock tunnel. WOZNY \& CZAJKA (1985) presented this species under the name $B$. eumenis. Their concept was adopted by RUZICKA (1988). ESKOV (1988) recommended the name $B$. simillimus for Central European populations. According to this author, $B$. eumenis is distinguished from other closely related species by the presence of ventral spines on tibiae I and II, and its distribution area does not exceed the western Yenisey blogeographical border (ESKOV in litt.). In Europe, B. simillimus is a glacial relict. Its occurrence is known from sandstone "rock cities" and from stony debris. B. simillimus is the dominant species in spider communities of block fields on the ridge of the Giant mountains (RUZICKA et al. ms.). Recently, 
this species has been found in stony debris in the Black Forest and the Vosges Mountains (BLICK 1991).

Lepthyphantes pulcher is a middle-European species living predominantly on rocks. ANTUS (1982) was able to trap this species on crystalline rocks only during night. During day the spiders were hidden in inaccessible fissures. Sandstone, however, forms no narrow fissures where the spiders might find shelter, and thus collecting this species on sandstone rocks was not a problem.

Tab. 3 The presence of selected splder species in the collections from sandstone "rock cities".

1 Adrspach-Teplice rocks (in total 82 species)

2 Ostas table mountaln (5 specles)

3 Broumovske steny walls (3 spp.)

4 Prachovske Skaly rocks (22 spp.)

5 Hruba Skala "rock clty' (4 spp.)

6 Besedicke Skaly rocks and Maloskalsko reglon (32 spp.)

7 Suche Skaly rocks (1 sp.)

8 Kokorinsko reglon (5 spp.)

9 Tiske Steny walls (11 spp.)

10 Labske Plskovce sandstones (10 spp.)

$\begin{array}{llllllllll}1 & 2 & 3 & 4 & 5 & 6 & 7 & 8 & 9 & 10\end{array}$

Bathyphantes simillimus

Lepthyphantes pulcher

Lepthyphantes alacris

Drapetisca socialis

Thyreosthenius parasiticus +

Pelocopsis elongata +

Nesticus cellulanus $\quad+$

Meta merianae

Meta menardi

Lepthyphantes nitddus

Diplocentria bidentata

Centromerus prudens

Typhochrestus digitatus +

Theridion bettenl

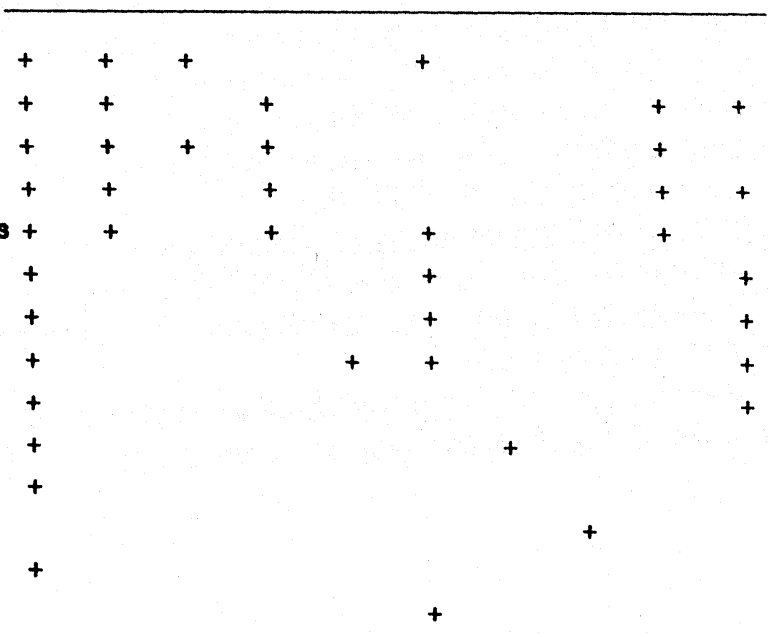


Lepthyphantes alacris is abundant on rocks surface and also on vegetation.

Noteworthy is the occurrence of the species Drapetisca socialis on the bare surface of rocks. This species was supposed to live only on tree bark (particularly beech) (LOCKET \& MILLIDGE 1953; WIEHLE 1956; MILLER 1971; WUNDERLICH 1982). It is likely that the occurrence of this species on rocks indicates the deciduous forests grown in this region, as the occurrence of some plant species indicates the original presence of beech forests in the Adrspach-Teplice rocks (DOHNAL 1952).

Thyreosthenius parasiticus lives in diverse biotopes which, however, have one thing in common, l.e. a wet and steady microclimate. Such an environment is provided by litter, decaying wood, bark spaces and tree hollows (KURKA 1981; RUZICKA et al. 1991) by compost and decaying hay (WIEHLE 1960), by animal burrows and bird nests (MILLER 1971), by farm buildings, cellars, sewers, mines (LOCKET \& MILLIDGE 1953) and, last but not least, by "rock cities".

Pelecopsis elongata is a forest detritus species. It is found in "rock cities" and in stony debris too.

Nesticus cellulanus and species of the genus Meta occupy shady rock niches and cave entrances.

Lepthyphantes nitidus (syn. L. kochi KULCZ.) has been found in two "rock cities", and beyond them, e.g., on claystone rocks near Bezdekovnad Metuji. Its occurrence has been reported from various sites (BUCHAR 1989; MAURER \& HÄNGGI 1990). However, in Poland it was always found under stones (CZAJKA 1963), which indicates an affinity for stony biotopes.

The find of Diplocentria bidentata in Teplicke Skaly rocks is the second record of this species in Czechoslovakia. It was first recorded by BUCHAR (1989) in stony debris on Plesivec Mountain in Ceske Stredohori Mts.

The species Centromerus prudens (O. P.-CBR., 1873) was for the first time found in Czechoslovakia after sieving moss from the "rock city" in the Kokorinsko region (BUCHAR 1989).

Typhochrestus digitatus is a photophilous and thermophilous species living on sandbanks and in lichen (TRETZEL 1952). In the open part of the VIci Rokle gorge in the Adrspach-Teplice rocks it was found in low moss growing on sunny rocks.

Theridion betteni is a photophilous and thermophilous species living on bare rocks surface. It was found on sunny rocks in the Maloskalsko region. 
The phenomenon of "rock cities" can manifest itself in three aspects.

1. The bottom parts of "rock cities" contain microclimatically cold spaces, frequently hosting northern or mountain species of invertebrate animals, which have an azonal occurrence (e.g. Bathyphantes simillimus, Centromerus pabulator, Dicymbium tibiale, Diplocephalus helleri, Lepthyphantes pulcher).

2. The sunexposed and parched tops of rocks with sparse, relict pines, on the other hand, can host some thermophilous species such as Theridion betteni and Typhochrestus digitatus.

3. Associated with the specific microclimate of the "rock cities", some invertebrate species live on the soil surface, in moss, on vegetation (e.g. Centromerus pabulator, Lepthyphantes mughi); other species, however, are limited to the stony substrate, to the surface of rocks and boulders. These are referred to as lithophilous or lithobiont species (e.g. Nesticus cellulanus, Theridion betteni, Bathyphantes simillimus, Lepthyphantes pulcher).

The fauna of invertebrate animals in "rock cities" certainly deserves more study, so that - along with the flora and the geomorphological character it should become an equally important subject for conservation in protected territories.

\section{ACKNOWLEDGEMENT}

I am deoply Indebted to all who took part in collecting and handling of the material and who provided me with the required data: Dr. K. ABSOLON ('rock clty' no. 1 (see Tab. 3)), Dr. P. ANDEL (7), M. ANTUS (1), Dr. P. BILEK $(5,6)$, Doc. Dr. J. BUCHAR (1), Dr. P. KASAL $(1,4$, $6,8)$, J. KOPECKY (1), F. RUZICKA (9), A. RUZICKOVA (1, 3), and L. RUZICKOVA (9). 
ANTUS, M. (1982): [Beltrag zur Kenntnis der Arachnofauna von Krkonose (Rlesengebirge)]. Opera corcontica 19:207-214 (in Czech, germ. abstr.)

BALATKA, B. \& J. SLADEK (1984): [The typology of the relief of block sandstones in the Bohemlan Cretaceous Basin]. - Rozpravy CSAV, r. MPV 94 (6):1-80 (in Czech, engl. abstr.)

BLICK, T. (1991): Bathyphantes eumenis, neu für Deutschland und Frankreich, sowie Lepthyphantes notabills aus Blockhalden (Araneae: Linyphildae). - Arachnol. Mitt. 2:31-32 BUCHAR, J. (1975): Arachnofauna Böhmens und ihr thermophiler Bestandtell. - Vest. cs. Spol. zool. 39 (4):241-250

BUCHAR, J. (1982): Publication of faunlstic data from Czechoslovakla. - Vest. cs. Spol. zool. 46:317.318

BUCHAR, J. (1983): [Dle Kassifikation der Splnnenarten Böhmens als ein Hilfsmittel für die BloIndlkation der Umwelt]. - Fauna Bohem. Septentr. 1983 (8):119-135 (in Czech, germ. abstr.)

BUCHAR, J. (1989): (The knowledge of the present Bohemian arachnofauna and its im provement to evaluation of development of natural conditions]. Diss. Charles University Praha, Fac. of Sciences. 206 pp. (in Czech)

CZAJKA, M. (1963): [Ropthyphantes kochiKULCZ. (Araneida, Linyphildae) in Poland]. Fragmenta faunistica 10 (20):303-308 (in Pollish)

DOHNAL, Z. (1950): [An overview of bryophytes in Adrspach-Teplice rocks]. Diss. Charles University Praha, Fac. of Sclences. 145 pp. (n Czech)

DOHNAL, Z. (1952): [An overvlew of vegetation in Adrspach-Teplice rocks]. - Csl. botanicke listy 4 (9):137-139 (in Czech)

ESKOV, K YU (1988): [Splders (Aranel) of Middle Siberia. In: Materials on fauna of Middle Siberla and nelghbouring area of Mongolla]. Institute of Evolutionary Animal Morphology and Ecology, USSR Academy of Sclences, Moscow:101-115 (in Russlan)

HEJNY, S. \& B. SLAVIK (1988): [Flora of the Czech Sociallst Republic I]. Academia, Praha. 560 pp. (in Czech)

KURKA, A. (1981): [Spinnen (Araneida) auf dem Stozec im Böhmerwald]. - Acta Mus. Nat. Pragae 38 B:47-78 (in Czech, germ. abstr.).

LOCKET, G. H. \& A. F. MILLIDGE (1953): British spiders. Vol. 2. Ray Soc., London. 449 pp. MAURER, R. \&A. HĀNGQI (1990): Katalog der schweizerischen Spinnen. Unpaginiert. CSCF, Neuchâtol

MILLER, F. (1971): [Order Splders - Araneida. In: M. DANIEL \& V. CERNY (Eds): Key to the fauna of Czechoslovakla]. Academia, Praha:51-306 (in Czech)

QUITT, E. (1975): Climatic reglons of the Czech Socialist Republic. In: Series of maps of physico-geographical regionalization of the Czech Socialist Pepublic. Institute of Qeography, Czechoslovak Academy of Sciences, Brno

RUZICKA, V. (1988): Problems of the species Bathyphantes eumenis (L. KOCH, 1879) and its occurrence in Czechoslovakla (Araneae, Linyphildae). - Vest. cs. Spol. zool. 52:149-155

RUZICKA, V., J. BOHAC \& J. MACEK (1991): (Invertebrate animals from hollow trees in the Trebon basin]. - Sbor. Jihoces. Muz. v Ces. Budejovicich, Prir, Vedy 31:33-46 (in Czech, engl. abstr.)

SLAVIK, B. (1984): Grundlegende Phytochorotypen der Tschechischen Sozlalistischen Republik. - Preslla, Praha 56:359-376 
SYKORA, T. \& E. HADAC (1984): [Contributlon to the phy togeography of the Adrspach-Teplice rocks complex]. - Preslla, Praha 56:359-376 (in Czech, engl. abstr.)

TRETZEL, E. (1952): Zur Ökologle der Spinnen (Araneae). Autökologle der Arten im Raum von Erlangen. - Sber. phys.med. Soc. Erlangen 75:36-131

VITEK, J. (1979): [Pseudokarst phenomena in block sandstones in north-east Bohemla]. Rozpravy CSAV, r. MPV 89 (4):1-57 (in Czech, engl. abstr.)

WIEHLE, H. (1956): Splnnentiere oder Arachnoidea (Araneae). 28. Famille LinyphildaeBaldachinspinnen. In F. DAHL (Ed): Die Tierwelt Deutschlands, 44 Teil. VEB Gustav Fischer Verlag, Jena. 339 pp.

WIEHLE, H. (1960): Spinnentiere oder Arachnoidea (Araneae). XI: Micryphantldae Zwergspinnen. In F. DAHL (Ed): Dle Tlerwelt Deutschlands, 47. Teil. VEB Gustav Fischer Verlag, Jena. $620 \mathrm{pp}$.

WOZNY, M. \& M. CZANKA (1985): Bathyphantes eumenis (L. KOCH, 1879) (Aranel, Linyphiidae) In Poland, and its synonyms. - Polskle pismo entom. 55:575-582

WUNDERLICH, J. (1982): Mitteleuropälschen Spinnen (Araneae) der Baumrinde. - Z. angew. Ent. 94 (1):9-21

RNDr. Vlastimil Ruzicka, CSc.

Institute of Landscape Ecology

Czechoslovak Academy of Sciences

Na sadkach 7

37005 Ceske Budejovice

CZECHOSLOVAKIA

Fig. 2 The territory of block sandstones in north-east Bohemla - dotted (after BALATKA \& SLADEK 1984). Silenumbers are defined in Tab. 3.

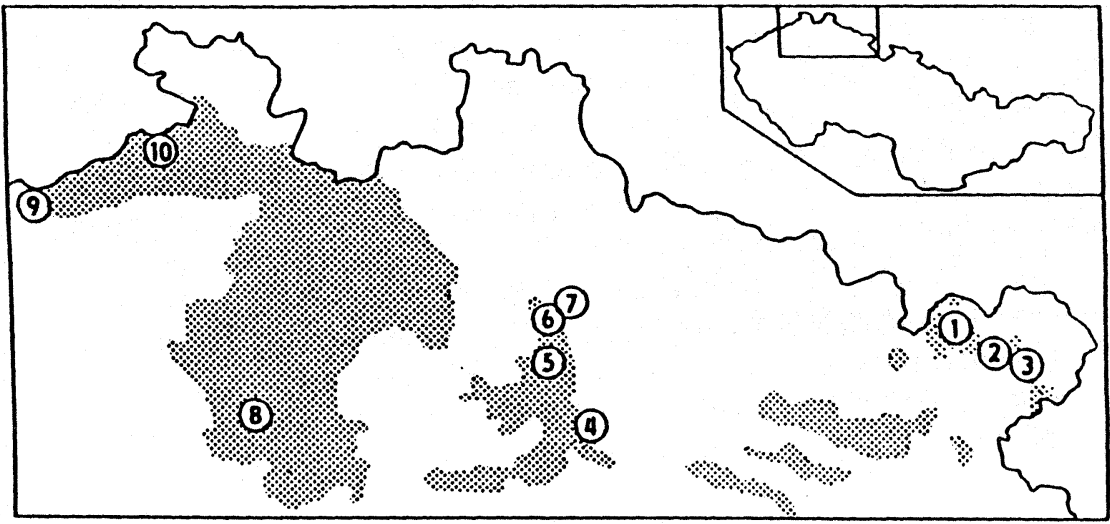

